\title{
THE EFFECT OF RIFAMPICIN AND DAPSONE ON EXPERIMENTAL MYCOBACTERIUM LEPRAE INFEC- TIONS: MINIMUM INHIBITORY CONCENTRATIONS AND BACTERICIDAL ACTION
}

\author{
I. B. Holmes AND G. R. F. Hilson \\ St George's Hospital Medical School, London
}

STUDIES on the chemotherapy of experimental human leprosy were made possible in 1960 by the demonstration of a limited infection with Mycobacterium leprae in the mouse footpad (Shepard, 1960). To begin with they were based mainly on the continuous administration of drugs from the day of inoculation, and subsequent assessment of their ability to suppress the growth of small inocula of $M$. leprae (Shepard and Chang, 1962, 1964; Rees, 1965; Gaugas, 1967). These studies were later extended by an assessment of the therapeutic action of drugs on established infections (Shepard and Chang, 1967), the viability of the organisms after drug treatment being tested by the tedious procedure of subinoculation into new groups of mice. Shepard (1967a) reported a " kinetic " technique of detecting the bactericidal action of drugs based on the treatment of inoculated mice for a limited period and measuring the subsequent delay in growth of the leprosy bacilli. Any delay exceeding that accounted for by bacteriostasis during administration and subsequent excretion of the drugs is taken to indicate that the growth must have developed from a number of viable bacilli smaller than that inoculated and hence that there has been a bactericidal effect. Results obtained with this technique suggested, for example, that dapsone is bactericidal to $M$. leprae, but only after 60 or more days of treatment (Shepard, 1967a, 1969a).

Rifampicin, a recently synthesised derivative of rifamycin, has been shown to be active both in vitro and clinically against $M$. tuberculosis, with bactericidal action (Grumbach and Rist, 1967; Pallanza et al., 1967; Verbist et al., 1967). When tested in the mouse footpad system it was found to be highly active against M. leprae (Rees, Pearson and Waters, 1970; Hilson, Banerjee and Holmes, 1972). The minimal effective dosage of the drug was, however, not determined.

The present paper reports the activity of rifampicin against three strains of $M$. leprae in the mouse footpad by continuous administration, and a comparison between dapsone and rifampicin by means of the kinetic method of Shepard.

\section{MATERIALS AND METHODS}

The approach employed was to follow the growth of $M$. leprae in the footpad of control and of drug-treated mice, according to the method of Shepard and Chang (1962).

Received 23 Sept. 1971; accepted 1 Nov. 1971.

J. MED. MICROBIOL.-VOL 5 (1972)

251 
Strains of Mycobacterium leprae. Three strains of $M$. leprae were used, all of them derived from previously untreated lepromatous leprosy cases. Strains SBL16263 and SBL16237 had undergone two and three mouse-passages respectively before use, while strain SBL16282 was transferred directly from a patient to mice.

Mouse inoculation and assessment of bacillary growth. P-strain mice were used in all studies. Small inocula in the left hind footpad were employed: $10^{4}$ acid-fast bacilli (AFB) per footpad for strains SBL16237 and SBL16282, and $5 \times 10^{3}$ AFB per footpad for SBL16263. For each of the three strains, 20 mice were used as untreated control animals, fed with pelleted mouse diet 41B (Oxoid). Treated animals received the same diet in powder form containing the appropriate concentrations of the drugs. The appropriate weighed amount of drug was finely ground and mixed into a portion $(10-20 \mathrm{~g})$ of powdered diet by means of a mortar and pestle. This mixture of drug and diet was then added to a quantity of powdered diet, usually $2.5 \mathrm{~kg}$, in the mixing cylinder of a " Rotamixer" mechanical blender (A. Gallenkamp \& Co. Ltd, London) and mixed for at least $10 \mathrm{~min}$. Batches of drug-diet mixture were stored in cans for up to $3 \mathrm{wk}$. Drug administration, when continuous, was started either on the day of inoculation or on day 75 post-inoculation; each concentration of dapsone (DDS) or rifampicin (RMP) being fed to a batch of eight mice. When of limited duration, administration of the drugs was started on day 31 post-inoculation and continued for either 30 or 60 days; each treated batch consisted of 15 mice. Calculations of drug dosage in terms of $\mathrm{mg}$ per $\mathrm{kg}$ were made on the basis of a daily consumption of $5 \mathrm{~g}$ diet by mice of $25 \mathrm{~g}$ average weight: e.g., 0.001 per cent. dietary dosage was taken to be equivalent to $2.0 \mathrm{mg}$ per $\mathrm{kg}$. In a complete titration, drug dosage was at approximately $0.5 \log _{10}$ intervals (e.g., $0.01,0.003,0.001$ $\ldots$ per cent.). The least dosage suppressing growth of AFB completely is expressed as the minimum inhibitory dosage (MID).

Harvests of AFB were made by killing several mice (usually three) from the control groups after 90 or 120 days post-inoculation at intervals and dissecting off the inoculated footpads. The treated groups were sampled similarly, but not until the AFB counts in the control animals had reached at least $10^{5}$ AFB per footpad. Homogenates of the footpads were made in Dubos liquid medium containing Tween 80 (pools of footpads in the case of control animals, and individual footpads in the case of treated animals); counts of AFB in homogenates were carried out by the method of Hilson and Elek (1957).

Serum rifampicin concentrations. Estimations were made of the concentration of RMP in the sera of individual treated mice. Each mouse was anaesthetised with ether and bled out by means of heart puncture. The sample of blood obtained was kept at $37^{\circ} \mathrm{C}$ for $1 \mathrm{hr}$ and then at $4^{\circ} \mathrm{C}$ overnight. The serum was separated and stored at $-20^{\circ} \mathrm{C}$ until the time of estimation of RMP content. The serum RMP concentration was measured by means of an agar diffusion technique for microbiological assay. Difco Penassay Seed Agar was melted and inoculated at $45^{\circ} \mathrm{C}$ with 1 per cent. (v/v) of a nutrient broth culture of a strain of Sarcina lutea, standardised on a Coleman "Junior" spectrophotometer to give 75 per cent. transmission at $540 \mathrm{~nm}$ through the culture tube $(1.4 \mathrm{~cm}$ internal diameter). Each petri dish $(8.5 \mathrm{~cm}$ diameter) received $15 \mathrm{ml}$ of seeded agar. Four evenly spaced circular wells $(8 \mathrm{~mm}$ diameter) were punched in the agar and sealed at the bottom with a drop of 0.5 per cent. agar. Each well received $0.025 \mathrm{ml}$ of serum to be assayed for RMP content. After incubation at $30^{\circ} \mathrm{C}$ for $18 \mathrm{hr}$, two diameters at right angles were measured on each inhibition zone and the mean diameter calculated. On every dish two wells were used for " reference point" control sera containing 1.0 and $0.25 \mu \mathrm{g}$ per ml RMP respectively.

For each batch of mouse sera to be tested, a standard graph of the logarithms of RMP concentrations against zone diameter was prepared for known concentrations of drug in horse serum ranging by twofold dilutions from 4.0 to $0.06 \mu \mathrm{g}$ per $\mathrm{ml}$; mean values were obtained from four replicate dishes for each concentration and plotted on semi-logarithmic graph paper. Mouse sera were diluted with horse serum according to expected RMP concentrations so as to give zone diameters near the middle of the standard range and three replicate dishes were used for each serum. For each mean zone diameter the corresponding serum concentration was obtained from the graph; in general, each recorded value of serum RMP concentration represented the mean of values obtained from a group of five or six mice. 


\section{RESULTS}

\section{Continuous administration}

The sensitivity of the three strains of Mycobacterium leprae to RMP and DDS was determined by continuous administration of graded doses of the drugs. DDS was administered in the case of all three strains at 0.0001 and 0.01 per cent. in the diet. RMP was administered at $0.0001,0.0003$ and 0.001 per cent. to mice infected with strains SBL16237 and SBL16282, and at 0.0001 and 0.01 per cent. to those infected with strain SBL16263. In the case of strain SBL16282 the start of treatment was delayed until day 75. Growth of all strains in control animals was monitored as described above; the harvests from each treated group consisted of samples of three to five mice and were made at the time when growth in control animals had reached the usual "plateau" level of approximately $10^{6}$ AFB per footpad, and 1 to 2 mth later.

All three strains of $M$. leprae were sensitive to 0.0001 per cent. DDS by continuous administration, growth being completely suppressed in all treated groups. RMP sensitivity varied amongst strains: of the three strains tested, SBL16282 was inhibited completely by 0.0003 per cent. RMP and partially by 0.0001 per cent.; SBL16237 was sensitive to 0.001 per cent. RMP and partially sensitive to 0.0003 per cent. The third strain (SBL16263) was sensitive to 0.01 per cent. but not to 0.0001 per cent.; its MID was not determined in this experiment, but its sensitivity to 0.001 per cent. may be inferred from the growth delay found subsequently in a kinetic experiment.

\section{Kinetic technique}

Groups of treated mice were fed from day 31 with 0.01 per cent. DDS or RMP for 30 or 60 days, or with 0.01 per cent. RMP for 60 days, after which the drug was withdrawn. Harvests from three control animals were made 120 days after inoculation and at intervals subsequently, and the pattern of growth of $M$. leprae in the treated groups was determined by harvests from two or three mice before early growth was expected, and three mice during logarithmic growth.

The figure records graphically the mean footpad counts of AFB obtained in these experiments. It shows that dietary administration of RMP 0.01 per cent., whether for 30 or for 60 days, led to complete failure of growth of $M$. leprae to appear during the period of observation. In the other three treated groups, the growth curves show delays varying in degree according to the drug regimen. The delay in days in these groups is shown in table I under the heading "Bacterial growth delay "; for the purposes of this table in the case of each curve the extent of displacement from the control of the point corresponding to a count of $10^{5 \cdot 3}$ was measured from the graphs shown in the figure. The least delay (49 days) was produced by the administration of 0.01 per cent. DDS for 30 days, and equal amounts of delay (about 90 days) were produced by either 0.01 per cent. DDS for 60 days or 0.001 per cent. RMP for 60 days. The considerations on which calculations of growth curve delay are based, and their significance, are discussed below. 


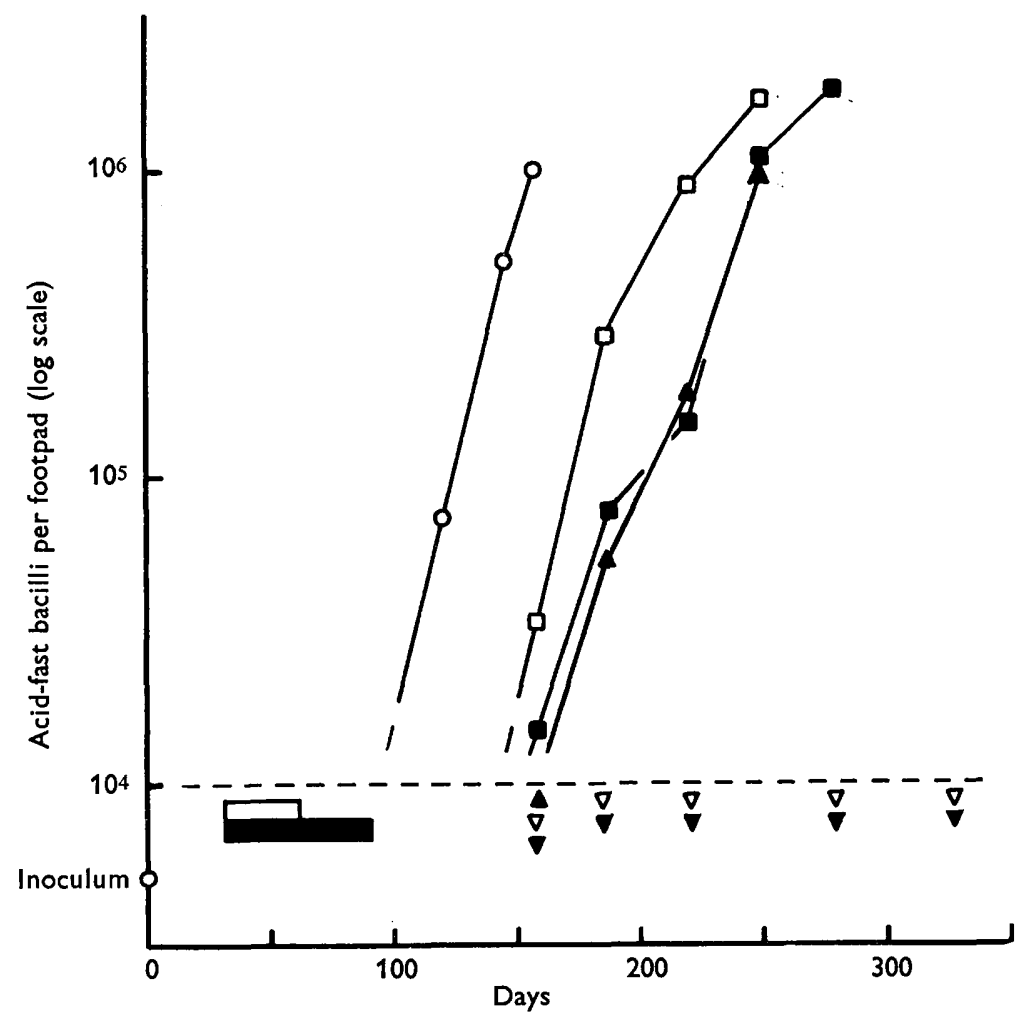

FIGURE.-Counts of acid-fast bacilli in the footpad of mice at various times after inoculation with $5 \times 10^{3}$ Mycobacterum leprae. The horizontal interrupted line indicates the threshold of sensitivity of the method: symbols shown below it indicate counts of, or fewer than, $10^{4}$ AFB per footpad. (O) counts in untreated control mice; $(\square)$ in mice receiving 0.01 per cent. dapsone for 30 days or $(\boldsymbol{\square})$ for 60 days; $(\boldsymbol{\Lambda})$ in mice receiving 0.001 per cent. rifampicin for 60 days; and $(\nabla)$ in mice receiving 0.01 per cent. rifampicin for 30 days or $(\nabla)$ for 60 days. The position in time of the 30 - and 60-day treatment periods is indicated respectively by the hollow and solid horizontal blocks below the interrupted line.

\section{TABLE I}

Delayed growth of M. leprae (strain SBL16263) following temporary dietary administration of dapsone $(D D S)$ or of rifampicin (RMP) and its interpretation in terms of the bactericidal action of the drugs

\begin{tabular}{l|c|c|c|c|c}
\hline \multicolumn{1}{|c|}{ Treatment regimen } & $\begin{array}{c}\text { Estimated } \\
\text { time for } \\
\text { excretion } \\
\text { (days) }\end{array}$ & $\begin{array}{c}\text { Estimated } \\
\text { time of } \\
\text { effective } \\
\text { exposure to } \\
\text { drug (days) }\end{array}$ & $\begin{array}{c}\text { Bacterial } \\
\text { growth delay } \\
\text { (days) }\end{array}$ & $\begin{array}{c}\text { Delay due to } \\
\text { bactericidal } \\
\text { effect } \\
\text { (days) }\end{array}$ & $\begin{array}{c}\text { Fraction } \\
\text { surviving } \\
\text { (per cent.) }\end{array}$ \\
\hline 0.01 per cent. DDS 30 days & 15 & 45 & 49 & 4 & $74 \cdot 7$ \\
0.01 per cent. DDS 60 days & 15 & 75 & 91 & 16 & 33.0 \\
0.001 per cent. RMP 60 days & 2 & 62 & 89 & 27 & 13.9 \\
0.01 per cent. RMP 30 days & 2 & 32 & $>234$ & $>202$ & $<0.02^{*}$ \\
0.01 per cent. RMP 60 days & 2 & 62 & $>234$ & $>172$ & $<0.02^{*}$ \\
\hline
\end{tabular}

* With the inoculum used $\left(5 \times 10^{3}\right.$ per footpad) a surviving fraction of $<0.02$ per cent. represents the failure of a single organism to survive. 


\section{Mouse-serum concentrations of RMP}

The results of estimating the concentration of RMP in the sera of mice receiving the drug for varying periods of time are shown in table II. This shows

TABLE II

Serum-rifampicin (RMP) concentrations in mice receiving dietary administration of 0.01 per cent. of the drug

\begin{tabular}{|c|c|c|c|}
\hline $\begin{array}{l}\text { Period of drug } \\
\text { administration } \\
\text { (days) }\end{array}$ & $\begin{array}{c}\text { Number of mice } \\
\text { examined }\end{array}$ & $\begin{array}{c}\text { Range of } \\
\text { serum RMP } \\
\text { concentrations } \\
(\mu \mathrm{g} \text { per ml })\end{array}$ & $\begin{array}{c}\text { Mean } \\
\text { serum RMP } \\
\text { concentrations } \\
(\mu \mathrm{g} \text { per ml) } \\
\text { with standard } \\
\text { errors }\end{array}$ \\
\hline $\begin{array}{r}1 \\
2 \\
4 \\
7 \\
14 \\
21 \\
45 \\
66\end{array}$ & $\begin{array}{l}3 \\
5 \\
5 \\
5 \\
6 \\
6 \\
6 \\
6\end{array}$ & $\begin{array}{l}2 \cdot 1-4 \cdot 8 \\
3 \cdot 5-8 \cdot 1 \\
4 \cdot 4-9 \cdot 5 \\
3 \cdot 4-7 \cdot 5 \\
3 \cdot 4-7 \cdot 7 \\
2 \cdot 4 \cdot 7 \cdot 7 \\
3 \cdot 0-6 \cdot 6 \\
1 \cdot 9-4 \cdot 1\end{array}$ & $\begin{array}{l}3.3 \pm 1.4 \\
5.9 \pm 1.9 \\
6.4 \pm 1.9 \\
5.8 \pm 1 \cdot 6 \\
4.9 \pm 1.6 \\
5.7 \pm 1.6 \\
4.2 \pm 1.7 \\
3.1 \pm 1.4\end{array}$ \\
\hline
\end{tabular}

that with dietary administration of 0.01 per cent. $(20 \mathrm{mg}$ per $\mathrm{kg}$ ), serum levels of approximately 6 per $\mathrm{ml}$ were achieved. There was a slight decrease in the serum concentrations after prolonged administration ( 45 days or more). It can also be seen that there was considerable variation in drug levels from one mouse to another at any given sampling.

TABLE III

Rifampicin concentrations in the sera of treated mice after 42 hours' dietary administration of 0.01 per cent. of the drug, and then withdrawal

\begin{tabular}{c|c|c}
\hline $\begin{array}{c}\text { Time in hours after } \\
\text { drug withdrawal }\end{array}$ & $\begin{array}{c}\text { Number of mice } \\
\text { in estimation }\end{array}$ & $\begin{array}{c}\text { Mean serum } \\
\text { concentrations } \\
\text { ( } \mu \text { g per ml) with } \\
\text { standard errors }\end{array}$ \\
\hline 0 & 6 & $5 \cdot 25 \pm 1 \cdot 63$ \\
6 & 5 & $3 \cdot 31 \pm 0 \cdot 83$ \\
24 & 5 & $0 \cdot 89 \pm 0 \cdot 65$ \\
30 & 5 & $0 \cdot 31 \pm 0 \cdot 17$ \\
48 & 5 & $0 \cdot 10 \pm 0 \cdot 03$ \\
100 & $50 \cdot 05$ \\
\hline
\end{tabular}

The rate at which RMP disappears from the bloodstream was determined. Mice were starved for $24 \mathrm{hr}$ and then RMP was administered for $42 \mathrm{hr}$ at 0.01 per cent. in the diet; serum RMP concentrations were determined at the time intervals shown in table III. The serum concentrations of antibiotic decreased with a half-life of $8-9 \mathrm{hr}$ and after 2 days had fallen to a value lower 
than the probable minimum inhibitory concentration (see below). At 4 days, RMP was no longer detectable in any sample of serum.

\section{DisCUSSION}

The minimum inhibitory concentration $(M I C)$ in serum of rifampicin $(R M P)$ and of dapsone $(D D S)$ for $M$. leprae

The in vivo titration of a drug for its suppressive action on a micro-organism requires examination of the effect of administering different dosages of the drug over a chosen period of time to inoculated animals. The minimum inhibitory dosage (MID) is the least dosage level that completely suppresses microbial growth (in this case the growth of $M$. leprae in the mouse footpad). However, the parameter essential for comparison between the results of animal tests and chemotherapy in man is the mean serum concentration achieved by administration of the MID. This value constitutes the serum minimum inhibitory concentration (MIC) of the drug. With cultivable organisms this is usually close to the conventional in vitro MIC.

The work of Rees et al. (1970) did not determine the minimum inhibitory dosage (MID) of RMP in the diet of $M$. leprae in the mouse footpad, although 0.0025 per cent. was found active against all 5 strains used. In the present study the MID was found to be 0.0003 per cent. for one strain and 0.001 per cent. for another. For the third strain the MID must have been equal to or less than 0.001 per cent. since this dosage was active in the kinetic experiment, but it was higher than 0.0001 per cent., which by continuous administration failed to suppress growth. It would therefore appear that for practical purposes the MID of RMP for the strains tested may be taken as 0.001 per cent. $(2 \mathrm{mg}$ per $\mathrm{kg}$ ). The effect of varying the dietary dosage of RMP on serum concentrations in mice is considered below. The relationship appears to be linear, and it is concluded that the MID of 0.001 per cent. $(2 \mathrm{mg}$ per $\mathrm{kg}$ ) produces a serum RMP concentration of $0.3 \mu \mathrm{g}$ per $\mathrm{ml}$; this may be therefore taken as the MIC for the strains of $M$. leprae tested.

Our value of the MID does not agree with that of Shepard (personal communication, 1970), who found that 0.001 per cent. dietary dosage of rifampicin was inactive; administration of 0.01 per cent. was both suppressive and bactericidal as judged by the kinetic method. The causes of this discrepancy are now under investigation: they may be related to differences between the two laboratories in the serum RMP level achieved with dosages (see below).

The growth of all three strains of $M$. leprae was suppressed by administration of 0.0001 per cent. DDS in the diet. This is in line with the findings of other workers (Shepard et al., 1966; Rees, 1967) for nearly all strains of M. leprae. The MIC, based on serum DDS concentrations obtained from this dosage, is between 0.01 and $0.03 \mu \mathrm{g}$ per ml. RMP is thus about ten times less potent weight for weight in its inhibitory action than is DDS. However, the main motive for the present investigations of RMP activity derives from the suggestion that it has a significantly greater bactericidal action on $M$. leprae (Rees et al.) than other anti-leprosy agents. 


\section{Bactericidal activity of RMP: assessment by the kinetic method}

The kinetic method, in attempting to distinguish bactericidal action of drugs on $M$. leprae from bacteriostatic action, relies on estimates of delay in the development of growth curves of AFB after a drug has been administered for a limited period. A delay equal to the time over which the drug has been given, added to the time required thereafter for the drug concentration in the animals to fall below the bacteriostatic level, is taken to indicate that only bacteriostasis has been achieved; precise knowledge of the excretion period is essential, and may be difficult to obtain. Any delay in excess of this amount might be due to a decrease in numbers of viable bacilli during the period of drug action (bactericidal effect), or to a "lag" while the organisms recover from this action before multiplication can begin (Dickinson and Mitchison, 1966), or to a combination of both. These aspects of the method have been discussed in detail by Shepard $(1967 a, 1969 a)$, who concluded that under defined conditions the degree of bactericidal action of drugs could be assessed by the technique on the basis of the amount of excess delay, which is referred to as "delay due to bactericidal effect". Estimates of bactericidal action obtained with the kinetic technique are consistent with those obtained by other methods for DDS (Shepard and Chang, 1967) and for RMP (Rees et al.). The measurement of bactericidal action by the method depends on calculating the proportional reduction in numbers of viable AFB that would give rise to the amount of growth delay measured.

For example, in the case of a strain of $M$. leprae with a mean generation time of 10 days, a reduction in viability to $1 / 8$ th $\left(2^{-3}\right)$ of the original value will produce a delay of $1 \mathrm{mth}$, compared with the controls, before a chosen numerical value on the growth curve is achieved. Our results (table I) will be discussed on the basis of these considerations.

Table I records the estimated bacterial growth delay in treated mice using the value of $10^{5.3}$ as the reference point on each growth curve (the figure). This point was chosen for the comparisons since all curves that appeared above the threshold of sensitivity of the counting method (104 AFB per footpad) were approximately parallel at this level and growth was in the middle logarithmic phase of increase. Calculated values of growth delay in excess of that attributable to bacteriostasis during the maintenance of effective blood levels of drug are shown in the column headed "delay due to bactericidal effect". The calculated bacteriostatic period is the period of administration plus the period of excretion. Thus, in the case of RMP $(0.01$ per cent.) this was 32 and 62 days respectively, assuming an excretion period of 2 days (table III); in the case of DDS ( 0.01 per cent.) it was 45 and 75 days (the excretion period of 15 days for DDS is taken from the work of Shepard (1967b). In table I the interpretation of Shepard (1969a) to account for the excess growth delay (" delay due to bactericidal effect" and "fraction surviving") was used for the purposes of compiling the table. It involves the adoption of a value for the rate of logarithmic growth of the strain of $M$. leprae used. This was obtained from the control curve in the figure, and expressed as a mean generation time of $9 \cdot 5$ days. 
Table I shows that DDS administration even for 60 days ( 75 days' effective exposure to a concentration 100 times greater than that required for inhibition) produced no significant bactericidal effect, a result which differs from that of Shepard (1969a). This might be due to differences in experimental conditions (e.g., the strain of $M$. leprae studied, and the strain of mice used) or to the earlier start of drug administration (at day 32 instead of day 104). The latter explanation would be consistent with the finding of a lesser bactericidal effect (16 per cent. survival) in one of his earlier experiments in which drug administration was also started on day 31 (Shepard, 1967a). In the case of earlier administration, the bacteria were probably not fully in the logarithmic phase of growth, and therefore possibly less sensitive to the lethal action of the drug.

The bactericidal action of RMP was found to be greater than that of DDS, confirming the previous findings of Rees et al. No growth of $M$. leprae appeared during the period of observation after administration of 0.01 per cent. RMP $(10 \times$ the MID) for 30 or 60 days. This finding corresponds to complete killing of the inoculated organisms. The lower dosage (0.001 per cent.) was inhibitory-as has been found for two other strains of M. leprae by Hilson et al. (1972) - and showed only a slight bactericidal effect (14 per cent. survival after 62 days' exposure). In practical terms, the minimum bactericidal dosage (MBD) of RMP is probably of the order of 0.003 per cent. which would indicate a serum minimum bactericidal concentration (MBC) of 1 to $2 \mu \mathrm{g}$ per $\mathrm{ml}$ when the drug is administered for 30 or more days; the highly effective dosage of 0.01 per cent. corresponds to a serum concentration of about $6 \mu \mathrm{g}$ per $\mathrm{ml}$ (table II).

A comparison can be made between the bactericidal action in serum of RMP administered to mice and its effect in clinical use. If it is assumed that the fall in viability of $M$. leprae exposed to RMP occurs on an exponential basis, the rate of killing may be expressed as the mean time required to cause a halving in viable numbers, or " survival half-life" $\left(\mathrm{T}_{\frac{1}{2}}\right)$. From the values for "fraction surviving " shown in table I, it can be calculated that for organisms exposed to a serum concentration of $0.3 \mu \mathrm{g}$ per ml the value of $\mathrm{T}_{\frac{1}{2}}$ is about 22 days, and for those exposed to $6 \mu \mathrm{g}$ per $\mathrm{ml}$ it is greatly reduced, being not more than $2 \frac{1}{2}$ days. In the clinical field, bactericidal action of a drug may be inferred from the rate of fall of the morphological index of AFB taken at intervals from the lesions of a treated patient (Rees and Valentine, 1962; Waters and Rees, 1962). In the work of Rees $e t$ al. the fall in morphological index of patients treated with $600 \mathrm{mg}$ RMP once daily is illustrated. It is exponential in character, and $\mathrm{T}_{\frac{1}{2}}$ is about 6 days. The serum RMP concentrations of patients of this regimen fluctuate through the day from about $15 \mu \mathrm{g}$ per ml down to about $0.5 \mu \mathrm{g}$ per $\mathrm{ml}$ (Porven and Canetti, 1968). The $\mathrm{T}_{\frac{1}{2}}$ value resulting from the effect of this range of RMP concentrations in patients' sera falls between those obtained in the mouse work. In the latter the higher and lower serum concentrations were numerically close to the extremes of the range in patients' sera; hence there appears to be a close correspondence between estimates of bactericidal action related to mouse serum concentrations of RMP and those which relate the degree 
of bactericidal action observed in patients with the serum concentrations achieved by the treatment regimen used.

\section{Serum RMP concentrations in mice}

In general, unless there are data to the contrary, it is reasonable to assume a direct relationship between dosage of a drug and serum concentrations. In the case of RMP there is already evidence to suggest that a direct relationship exists (Hilson et al.). In the range of dietary dosages of 0.1 per cent. and 0.01 per cent. serum values of 15-30 $\mu \mathrm{g}$ per ml and 2-4 $\mu \mathrm{g}$ per ml respectively were found. In that work, the method of assay differed, but the value obtained for 0.01 per cent. dietary dosage was essentially the same as that found in the present work (table II). Preliminary findings in work to be reported later, in which 0.001 per cent. of drug was given, showed that serum concentrations of RMP approximated to the value of $0.3 \mu \mathrm{g}$ per $\mathrm{ml}$ which would have been expected by extrapolation from the results obtained in the present work. It seems therefore that in the range of dosage studied there is indeed a linear relationship between dietary dosage of RMP and the concentration of drug in the serum of mice of the strain used.

Continued administration of 0.01 per cent. RMP for a period of 66 days resulted in relatively constant serum concentrations, although there appeared to be a slight fall at the end of the period (45-66 days after the beginning of administration). These findings differ from those in human patients undergoing treatment for tuberculosis with RMP. Brouet et al. (1969) found a tendency towards reduction of average daily serum concentrations during administration of 450 mg RMP twice daily, with considerable variation between individuals; levels might fall to 50 per cent. of initial value after 30 days, and to 10 per cent. after 60 days. Similar results were obtained by Constans et al. (1968). Shepard (personal communication, 1971) also reported falling serum concentrations in mice maintained on RMP dietary administration at levels from 0.001 to 0.1 per cent. Although there is a discrepancy between his findings and ours as to the MID, it should be noted that our value of $0.3 \mu \mathrm{g}$ per $\mathrm{ml}$ for the MIC (corresponding to a dietary dosage of 0.001 per cent.) was in fact achieved in his work (4.1-0.8 $\mu$ g per ml) by the higher dosage of 0.01 per cent. which he found suppressive; it was not produced (less than $0.2 \mu \mathrm{g}$ per ml) by the administration of 0.001 per cent., which he found to be ineffective. The over-all results, therefore, if considered in terms of the MIC in mouse serum, are not inconsistent. They suggest, prima facie, a difference between his mouse strain and ours in the response to RMP administration.

The half-life of RMP in the blood of mice after cessation of 48 hours' treatment with 0.01 per cent. dietary dosage is 8 to $9 \mathrm{hr}$; after 2 days a concentration effective against $M$. leprae is no longer present. It is clear that no accumulation of RMP occurs at these dosage levels and therefore with this drug no problems arise in the calculations used in analysing the results obtained by the kinetic technique. If a drug accumulates to a significant extent, as is the case with the riminophenazine drugs, much less clear conclusions may be drawn as to their bactericidal action by means of this technique (Shepard, 1969b). 


\section{SUMMARY}

The sensitivity of three strains of Mycobacterium leprae to dapsone (DDS) and rifampicin (RMP), administered continuously in the diet, was determined in the mouse footpad system. All three strains were inhibited by 0.0001 per cent. DDS. Sensitivity to RMP varied, the minimum inhibitory dose (MID) being 0.001 per cent. for two strains and 0.0003 per cent. for the third.

During the administration of 0.01 per cent. RMP, the concentrations of RMP in mouse serum, estimated by microbiological assay, was relatively constant at about $6 \mu \mathrm{g}$ per $\mathrm{ml}$ over a 66-day period. The considerations for assuming a linear relationship between dietary dosage and the resultant serum concentration are discussed. It is inferred that a minimum inhibitory dose of RMP for $M$. leprae of 0.001 per cent. is equivalent to a minimum inhibitory concentration for the organism of $0.3 \mu \mathrm{g}$ per $\mathrm{ml}$.

The bactericidal action of DDS and of RMP on $M$. leprae was assessed by means of the kinetic technique of Shepard. The DDS treatment used apparently had no significant bactericidal effect. The bactericidal action of RMP was found to be relatively high, confirming the previous finding of Rees et al. in patients with lepromatous leprosy. Complete killing of $M$. leprae was obtained after 30 days' treatment with 0.01 per cent. RMP in the diet (equivalent to a serum concentration of about $5 \mu \mathrm{g}$ per $\mathrm{ml}$ ). The relationship between the concentration of RMP in the serum of mice and its bactericidal action on $M$. leprae appears to be very similar to the corresponding relationship found in patients treated with the drug.

We are grateful to Messrs Lepetit Pharmaceuticals, Ltd, for supplies of rifampicin. This work was supported by Grant No. R1964 of the Overseas Development Administration.

\section{REFERENCES}

Brouet, J. H., ModaI, J., AND Vergez, P. 1969. Essais cliniques de la rifampicine en monothérapie. Etude des taux sériques. Revue Tuberc., 33, 27.

Constans, P., Saint-Paul, M., Morin, Y., Bonnaud, G., AND Bariety, M. 1968. Rifampicine: première étude des dosages plasmatiques au cours de traitements prolongés chez des tuberculeux pulmonaires. Revue Tuberc., 32, 991.

Dickinson, JeAn M., AND Mitchison, D. A. 1966. In vitro studies on the choice of drugs for intermittent chemotherapy of tuberculosis. Tubercle, Lond., 47, 370.

GaUGas, J. M. 1967. Antimicrobial therapy of experimental human leprosy (Myco. leprae) infection in the mouse foot pad. Lepr. Rev., 38, 225.

GrUmBACH, F., AND RIST, N. 1967. Activité antituberculeuse expérimentale de la rifampicine dérivé de la rifamycine SV. Revue Tuberc., 31, 749.

Hilson, G. R. F., BANERJEe, D. K., AND Holmes, I. B. 1972. The activity of various antituberculous drugs in suppressing experimental Mycobacterium leprae infection in mice. Int. J. Lepr., in press.

Hilson, G. R. F., AND Elek, S. D. 1957. Intratesticular multiplication of Mycobacterium lepraemurium in normal and suramin-treated animals. Int. J. Lepr., $25,380$.

Nitti, V., Catena, E., Bariffi, F., and Delle Veneri, F. 1967. L'attività terapeutica della rifampicina nella tubercolosi polmonare. Arch. Tisiol., 22, 417.

Pallanza, R., Arioli, V., Furesz, S., and Bolzon, G. 1967. Rifampicin: a new rifamycin. II Laboratory studies on the antituberculous activity and preliminary clinical observations. Arzneimittel-Forsch., 17, 529. 
Porven, G., and Canetti, G. 1968. Les taux de rifampicine dans le sérum de l'homme. Revue Tuberc., 32, 707.

ReEs, R. J. W. 1965. Recent bacteriologic, immunologic and pathologic studies on experimental human leprosy in the mouse foot pad. Int. J. Lepr., 33, 646.

ReEs, R. J. W. 1967. Drug resistance of Mycobacterium leprae, particularly to DDS. Int. J. Lepr., 35, 625.

Rees, R. J. W., AND Valentine, R. C. 1962. The appearance of dead leprosy bacilli by light and electron microscopy. Int. J. Lepr., 30, 1.

Rees, R. J. W., Pearson, J. M. H., and Waters, M. F. R. 1970. Experimental and clinical studies on rifampicin in treatment of leprosy. Br. Med. J., 1, 89.

Shepard, C. C. 1960 . The experimental disease that follows the injection of human leprosy bacilli into foot-pads of mice. J. Exp. Med., 112, 445.

ShEPARD, C. C. $1967 a$. A kinetic method for the study of activity of drugs against Mycobacterium leprae in mice. Int. J. Lepr., 35, 429.

SHEPARD, C. C. $1967 \mathrm{~b}$. Activity of repository sulfones against Mycobacterium leprae in mice. Proc. Soc. Exp. Biol. Med., 124, 430.

SHEPARD, C. C. $1969 a$. Further experience with the kinetic method for the study of drugs against Mycobacterium leprae in mice. Activities of DDS, DFD, ethionamide, capreomycin and PAM 1392. Int. J. Lepr., 37, 389.

ShEPARD, C. C. $1969 \mathrm{~b}$. Minimal effective dosages in mice of clofazimine (B 663) and of ethionamide against Mycobacterium leprae. Proc. Soc. Exp. Biol. Med., 132, 120.

SHEPARD, C. C., AND ChANG, Y. T. 1962. Effect of several antileprosy drugs on multiplication of human leprosy bacilli in foot-pads of mice. Proc. Soc. Exp. Biol. Med., 109, 636.

ShePARD, C. C., AND ChaNG, Y. T. 1964. Activity of antituberculosis drugs against Mycobacterium leprae. Studies with experimental infection of mouse footpads. Int. J. Lepr., $32,260$.

Shepard, C. C., AND Chang, Y. T. 1967. Effect of DDS on established infections with Mycobacterium leprae in mice. Int. J. Lepr., 35, 52.

Shepard, C. C., McRae, Dorothy H., and Habas, JANet A. 1966. Sensitivity of Mycobacterium leprae to low levels of 4,4'-diaminodiphenyl sulfone. Proc. Soc. Exp. Biol. Med., $122,893$.

Verbist, L., Gyselen, A., Cosemans, J., And Prignot, J. 1967. Preliminary results with rifampicin in the retreatment of multiresistant pulmonary tuberculosis in ten salvage cases. Proc. Vth Int. Congr. Chemother. (Vienna), edited by K. H. Spitzy and H. Haschek, $\Pi / 2,591$.

WATERS, M. F. R., AND REES, R. J. W. 1962. Changes in the morphology of Mycobacterium leprae in patients under treatment. Int. J. Lepr., 30, 266. 